\title{
Holdninger til legesøkning - variasjoner etter sosial tilhørighet?
}

\author{
Engelsk oversettelse av hele artikkelen på www.tidsskriftet.no
}

\begin{abstract}
Sammendrag
Bakgrunn. Økende sosioøkonomiske ulikheter i helse, nasjonalt som internasjonalt, gjør det betimelig å spørre: Er det systematiske forskjeller mellom folk av ulik sosial tilhørighet når det gjelder hvordan de stiller seg til det å søke profesjonell legehjelp når de opplever kroppslige plager av ulike slag?
\end{abstract}

Materiale og metode. Datamaterialet er hentet fra den norske delen av tverrsnittsundersøkelsen European Social Survey (2004-05). Analysene bygger på data fra personlige intervjuer med 741 menn og 694 kvinner i alderen 25-75 år. Samvariasjon mellom utdanningsnivå og holdninger til legesøkning, gitt fire mindre alvorlige hypotetiske symptomer, er analysert ved logistisk regresjon.

Resultater. Andelen som svarte at de ville $s ø k t$ legehjelp sank med økt utdanning. I ujusterte analyser var de utdanningsrelaterte forskjellene statistisk signifikante mellom laveste og høyeste utdanningsnivå ved samtlige symptomscenarioer for begge kjønn. I justerte analyser besto dette mønsteret kun for kvinner: Kvinner med laveste utdanningsnivå valgte lege oftere enn kvinner med høyeste utdanningsnivå, med en oddsratio fra 1,62 (95\% KI 1,02-2,56) ved kraftig hodepine, til $2,24(95 \% \mathrm{KI}$ $1,40-3,58)$ ved sår hals.

Fortolkning. Funnene indikerer at holdninger til legesøkning - forstått som hvordan folk mener at de bør tenke og handle, og hva de mener kan anses som sosialt akseptabelt i gitte situasjoner, varierer systematisk med utdanningsnivå.
Birgitte Klüwer-Trotter

Olaug S. Lian

olaug.lian@uit.no

Institutt for samfunnsmedisin

Universitetet i Troms $\varnothing$

Nyere forskning tyder på at sosioøkonomiske ulikheter i helse øker, selv i et egalitært samfunn som Norge, og en sentral målsetting $i$ norsk helsepolitikk er å redusere slike ulikheter (1-2). For å lykkes i dette arbeidet må vi forstå hvilke mekanismer som ligger bak ulikhetene. Her er det mange forskjellige teorier, og liten faglig enighet om hvilken teori som best forklarer ulikhetene.

I denne artikkelen tar vi utgangspunkt i trekk ved befolkningen, avgrenset til faktorer knyttet til holdninger til legesøkning. Med holdninger menes her en relativt varig normativ innstilling som sier noe om hvordan vi mener vi bør tenke og handle - ikke hvordan vi faktisk handler (3). Eksisterer det systematiske forskjeller i måten folk i ulike sosiale lag stiller seg til det å søke profesjonell helsehjelp når de opplever ulike kroppslige plager? Spørsmålet drøftes på bakgrunn av statistisk analyse av intervjudata fra den norske studien som inngikk i European Social Survey 2004/2005, der holdninger til bruk av helsetjenester var et sentralt tema $(4,5)$.

\section{Materiale og metode}

European Social Survey (ESS) er en europeisk tverrsnittsundersøkelse som siden 2002/2003 har vært gjennomført hvert annet år i mer enn 20 land. Populasjonen omfatter alle individer 15 år og eldre bosatt i private husholdninger i det enkelte deltakerland. Utvalgene selekteres etter prosedyrer for tilfeldige utvalg. Selve datasamlingen gjennomføres som personlige intervjuer ansikt til ansikt av omtrent én times varighet, og alle intervjuere trenes etter ESS' retningslinjer - utfyllende informasjon finnes på nettet $(4,5)$. I Norge er studien utført av Statistisk sentralbyrå på oppdrag fra Norges forskningsråd. Alle data er fritt tilgjengelige via internett (6). Data anvendt her er fra en modul om helse og helsetjenester som kun ble gjennomført i runde 2 (2004/2005).

\section{Utvalg}

Det norske utvalget ble trukket i ett trinn ved tilfeldig uttrekk fra Folkeregisteret. En responsrate på $66 \%$ ga et nettoutvalg på 1760 respondenter i alderen 15-94 år $(5,7)$. I ana- lysene beskrevet her er utvalget begrenset til respondenter i alderen 25-75 år. Respondenter under 25 år (235 personer) ble ekskludert fordi vi bruker utdanningsnivå som indikator for sosioøkonomisk posisjon, og blant de yngste er det trolig mange som ikke er ferdig utdannet (8). Avgrensningen ned til 75 år (90 personer utelatt) er videre begrunnet $i$ at seleksjonsmetoden ikke gir anledning til å ekskludere hjemmeboende som på grunn av utvidet kontakt med helsevesenet ikke lenger har et fullt ut selvstendig ansvar for å vurdere behovet for legehjelp. Etter disse avgrensningene endte utvalget på 1435 respondenter, hvorav 694 kvinner og 741 menn.

\section{Uavhengige variabler}

Som indikator for sosioøkonomisk posisjon brukte vi utdanning. Dette på grunn av variabelens praktiske fortrinn - så som en innebygd rangordning, stabilitet over livsløpet og få manglende verdier - samt at utdanning antas å være en av de viktigste mekanismene i den sosiale differensieringen i vårt samfunn (8). Utdanningsvariabelen er selvrapportert og måler formell kompetanse ved spørsmålet «Hva er din høyeste utdanning?». Respondentene ble gitt ni svaralternativer, fra 0 - ingen utdanning til 8 - forskernivå, doktorgrad. Variabelen ble rekodet til tre kategorier i henhold til Norsk standard for utdanningsgruppering, NUS 2000, hvor den tredelte nivåinndelingen er den som fremheves til analyseformål (9) (e-tab 1).

Videre brukte vi informasjon om alder, kjønn, og selvrapportert helse. Alder ble inkludert $\mathrm{i}$ analysene som en kontinuerlig variabel med 25 år som referanseverdi. Helsevariabelen ble inkludert for å justere for utdanningsrelaterte helseforskjeller, men også fordi dårlig helsetilstand i seg selv kan tenkes å påvirke holdninger til bruk av legetje-

\section{Hovedbudskap}

- Jo høyere utdanning, jo lavere var andelen som svarte at de ville søkt legehjelp for de angitte plagene

- For kvinner gjaldt sammenhengen mellom utdanning og hypotetisk legesøkning også etter justering for helse og alder

- Utdanning kan derfor være en viktig normdannende faktor når det gjelder holdninger til legesøkning 
nester - for eksempel ved et økt hjelpebehov, som igjen kan gi økt erfaring med systemet og påvirke opplevelsen av dets hjelpeevne. Respondentene ble med spørsmålet «Hvordan er helsen din stort sett?» bedt om å angi sin helsetilstand ut fra fem svaralternativer: 1- svært god, 2- god, 3- middels, 4- dårlig, og 5- svært dårlig. I tråd med en mye brukt inndeling ble variabelen dikotomisert slik at middels, dårlig og svært dårlig helse utgjør kategorien «dårlig helse» (10).

Vi vurderte innledningsvis også å inkludere to variabler på sosialt nettverk; den første basert på spørsmålet om hvorvidt respondenten hadde noen å betro seg til, den andre på frekvensen av sosial omgang. Førstnevnte ble ekskludert fordi andelen som ikke hadde noen å betro seg til var meget beskjeden, og fordi p-verdien var $>0,25$ for flere av holdningsvariablene $\mathrm{i}$ univariable analyser. Utfordringen med lave andeler i enkelte kategorier gjorde seg gjeldende også for variabelen på frekvensen av sosial omgang. Kombinert med at variabelens utforming gjorde det vanskelig å rekode uten et vesentlig informasjonstap, førte dette til at også denne variabelen ble ekskludert fra de multivariable analysene.

\section{Avhengige variabler}

Datasettet inkluderer fire holdningsvariabler der respondentene ble bedt om å angi sin antatte hjelpestrategi med utgangspunkt i fire hypotetiske symptomer: Sår hals, kraftig hodepine, alvorlige søvnproblemer og sterke ryggsmerter. «Hvis du hadde (...), hvem ville du gå til først for råd eller behandling?». Svaralternativene omfattet: 1- ingen, 2- venner eller familie, 3- apotek eller medisinutsalg, 4- lege, 5- sykepleier, 6 Internett, 7- en medisinsk opplysningstelefon, og 8alternative behandlere. Vi var primært interessert $\mathrm{i}$ forskjellen mellom dem som valgte «lege» versus dem som valgte andre alternativer, og de fire variablene ble dikotomisert deretter. Ettersom personlige variasjoner i sykehistorie/-erfaringer kan påvirke valget for enkeltsymptom $\mathrm{i}$ vel så stor grad som betydningen av sosial tilhørighet, er de fire dikotome variablene også slått sammen til én samlevariabel der respondenter som oppga «lege» som primær hjelpestrategi ved alle fire symptomer er skilt fra de øvrige.

\section{Analyse}

Hensikten med analysene var å undersøke hvorvidt holdninger til legesøkning, operasjonalisert som angitt primær hjelpestrategi ved ulike symptomscenarioer, samvarierer systematisk med sosioøkonomisk posisjon, målt ved utdanningsnivå. Bivariate krysstabeller og Pearsons khikvadrattest ble benyttet for å få et bilde av respondentenes holdninger etter valgte sosiodemografiske kjennetegn. Mulige assosiasjoner mellom utdanning og helse på den ene siden, og rapportert intensjon om å søke lege gitt hypotetiske symptomer på den annen, ble siden

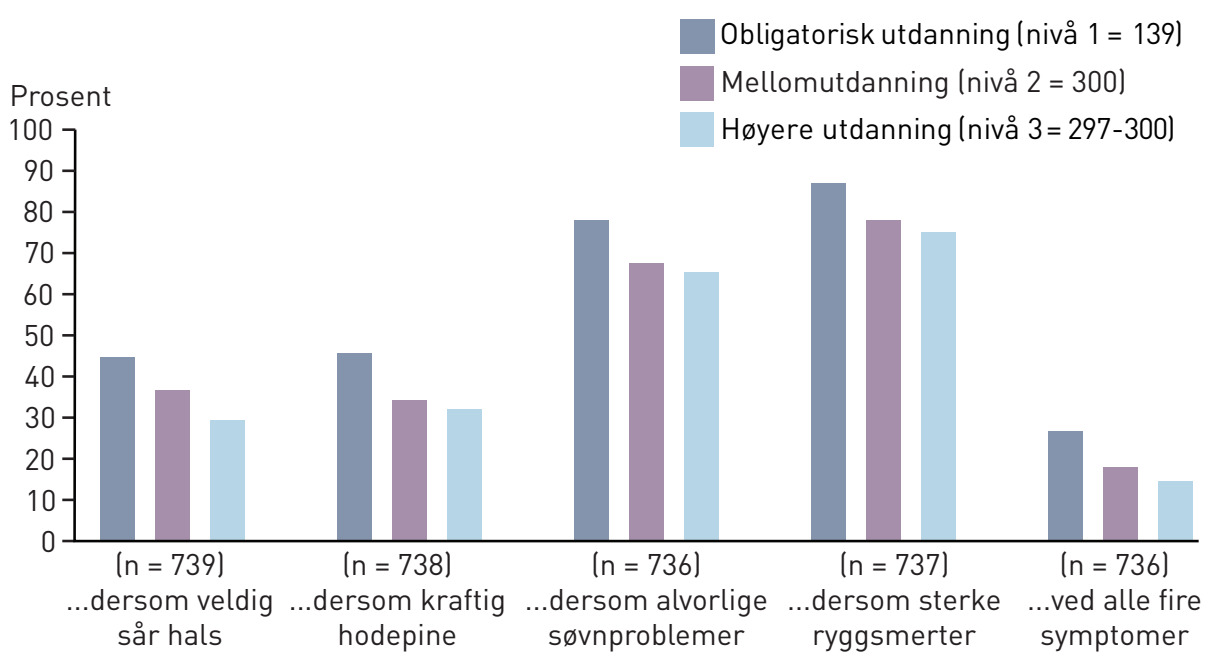

Figur 1 Andel menn (\%) innenfor hvert utdanningsnivå som valgte «lege» ved spørsmål om deres primære hjelpestrategi gitt ulike hypotetiske symptomscenarioer testet ved univariabel og multivariabel logistisk regresjon for hvert kjønn. I de multivariable analysene ble de uavhengige variablene lagt til trinnvis: først alder, deretter utdanningsnivå, og til sist helsetilstand. Dette ble gjort for å se om betydningen av forklaringsvariablene endret seg når flere variabler ble inkludert i modellen. Til analysene sjon 16.0).

\section{Etikk}

Alle data ble anonymisert i etterkant av undersøkelsen, som ble gjennomført i henhold til personopplysningslovens bestemmelser.

\section{Resultater}

E-tabell 2 viser hvordan utvalget fordelte seg etter de uavhengige variablene.

\section{Kjønn}

Blant kvinnene varierte andelen som valgte lege ved de ulike symptomene $\mathrm{i}$ området benyttet vi statistikkprogrammet SPSS (ver-
$32,9-75,6 \%$, blant mennene i området $34,3-77,6 \%$ (e-tab 3).

Khikvadrattester av kjønnsforskjellen innenfor hvert enkelt utdanningsnivå viste at forskjellen i angitt legesøkning kun var statistisk signifikant mellom menn og kvinner belen: $13,8 \%$ av mennene mot $8,3 \%$ av kvinnene valgte lege ved alle fire sympto$\operatorname{mer}(\mathrm{p}=0,035$; fig 1 og 2$)$.

I tilsvarende tester blant respondenter av henholdsvis god og dårlig helse var kjønnsforskjellen kun statistisk signifikant for samlevariabelen, hvor $26,3 \%$ av mennene mot $17,3 \%$ av kvinnene med dårlig helse valgte lege $(p=0,038$; e-fig 3 og e-fig 4$)$.

\section{Utdanning}

Andelen som ga uttrykk for at de ville søke lege, var høyest blant respondenter med inntil obligatorisk utdanning, før den minket for hvert trinn opp utdanningsstigen. Dette mønsteret kom til syne for alle holdningsvariablene med høyeste utdanningsnivå på samlevaria-

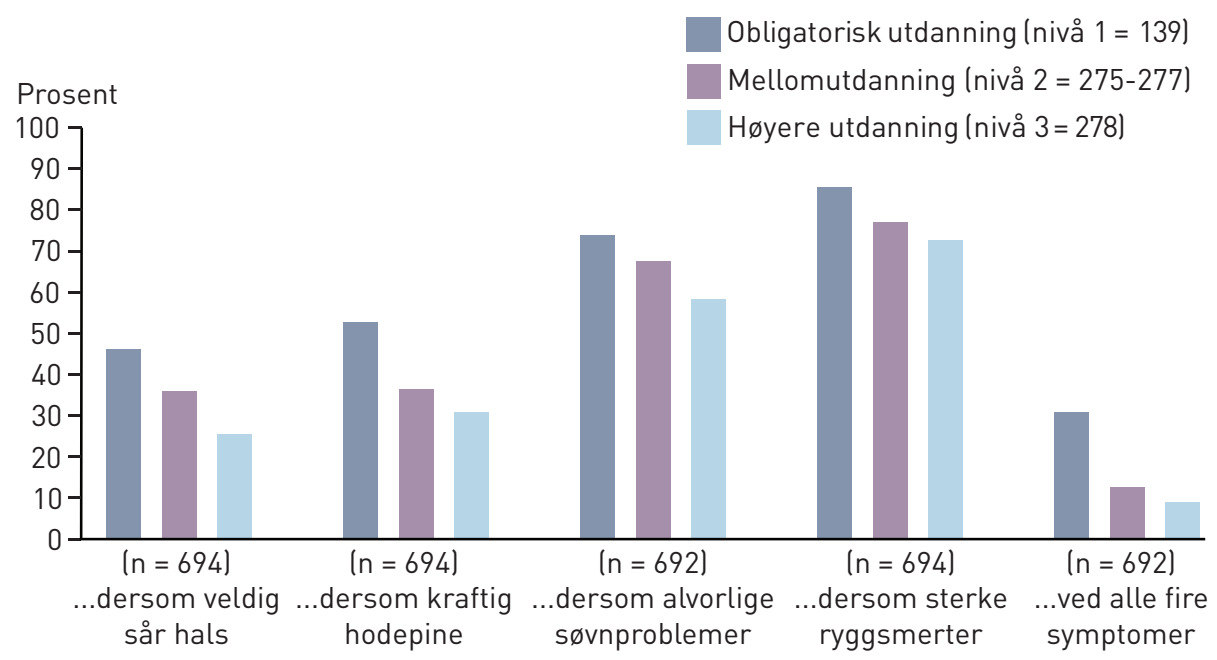

Figur 2 Andel kvinner (\%) innenfor hvert utdanningsnivå som valgte «lege» ved spørsmål om deres primære hjelpestrategi gitt ulike hypotetiske symptomscenarioer 
for begge kjønn. Forskjellen mellom laveste og høyeste utdanningsnivå var dog gjennomgående større for kvinner (fig $1 \circ \mathrm{og} 2$ ).

I de univariable logistiske regresjonsanalysene hadde respondenter med laveste utdanningsnivå blant både menn og kvinner gjennomgående statistisk signifikant høyere odds for å velge lege sammenliknet med respondenter med høyeste utdanningsnivå (tab 4 og 5).

I de multivariable analysene var det justert for alder kun for symptomet «sterke ryggsmerter» at menn med obligatorisk utdanning hadde statistisk signifikant høyere odds for å velge lege, og da helsetilstand ble inkludert i modellen, falt også denne sammenhengen bort (tab 4). For kvinnene var derimot alle de utdanningsrelaterte forskjellene $\mathrm{i}$ angitt legesøkning statistisk signifikante selv etter kontroll for både alder og helsetilstand (tab 5).

\section{Helsetilstand}

Krysstabulering mellom selvrapportert helsetilstand og holdningsvariablene viste at ande- len som valgte lege, gjennomgående var høyere blant respondenter med dårlig enn blant respondenter med god helse. Mønsteret var det samme for begge kjønn; forskjellene var imidlertid større blant mennene (e-fig 3 og e-fig 4).

I univariable analyser ga dårlig helsetilstand en statistisk signifikant høyere odds for å velge lege ved alle holdningsvariablene for mennene (tab 4), og ved tre av holdningsvariablene - kraftig hodepine, alvorlige søvnproblemer og sterke ryggsmerter for kvinnene (tab 5).

I multivariable analyser, der estimatene for helsetilstand var kontrollert for alder og utdanningsnivå, var sammenhengen fremdeles statistisk signifikant for tre av holdningsvariablene for mennene (kraftig hodepine, sterke ryggsmerter og samlevariabelen), mens for kvinnene var det ingen statistisk signifikant sammenheng.

\section{Diskusjon}

Analyse av norske intervjudata indikerer at det blant kvinner foreligger statistisk signifi- kante forskjeller mellom utdanningsgrupper $i$ holdninger til legesøkning ved mindre alvorlige plager, også etter kontroll for alder og helsetilstand: Andelen som hevder de ville søkt lege, er gjennomgående høyere blant kvinner med lavere utdanningsnivå for samtlige av de undersøkte hypotetiske symptomscenarioer.

\section{Hva ligger bak holdningsforskjellene mellom utdanningsgruppene?}

Det er her viktig å understreke at vi kun har sett på hypotetisk legesøkning; disse dataene kan således ikke fortelle hvorvidt de observerte mønstrene samsvarer med faktiske bruksmønstre for disse gruppene. Det er en mulighet for at respondentene rapporterer hjelpestrategier som de anser som mer sosialt akseptable (7). Likeledes er en uttrykt intensjon om å søke lege ingen garanti for at lege faktisk kontaktes når behovet oppstår, da en lang rekke faktorer kan begrense personens handlefrihet i den aktuelle situasjonen - enten vedkommende kan eller ikke kan rå for disse omstendighetene $(3,11)$.

Tabell 4 Logistiske regresjonsanalyser, menn: Ville gått til lege først for råd eller behandling dersom de hadde (...)

\begin{tabular}{|c|c|c|c|c|c|c|c|c|c|c|c|}
\hline & \multirow[b]{3}{*}{ Uavhengige variabler } & \multicolumn{10}{|c|}{ Avhengige variabler (holdningsvariabler) } \\
\hline & & \multicolumn{2}{|c|}{$\begin{array}{c}\text {...veldig } \\
\text { sår hals } \\
\text { (n= 739-741) }\end{array}$} & \multicolumn{2}{|c|}{$\begin{array}{c}\text {...kraftig } \\
\text { hodepine } \\
(n=738-740)\end{array}$} & \multicolumn{2}{|c|}{$\begin{array}{c}\text {...alvorlige } \\
\text { søvnproblemer } \\
\text { ( } \mathrm{n}=736-738 \text { ) }\end{array}$} & \multicolumn{2}{|c|}{$\begin{array}{c}\text {...sterke } \\
\text { ryggsmerter } \\
\text { (n= }=737-739 \text { ) }\end{array}$} & \multicolumn{2}{|c|}{$\begin{array}{c}\text {...alle fire } \\
\text { symptom } \\
(n=736-738)\end{array}$} \\
\hline & & OR & $95 \% \mathrm{KI}$ & OR & $95 \% \mathrm{KI}$ & OR & $95 \% \mathrm{KI}$ & OR & $95 \% \mathrm{KI}$ & OR & $95 \% \mathrm{KI}$ \\
\hline \multirow[t]{9}{*}{1.} & Alder i år & 1,03 & $1,02-1,05$ & 1,03 & $1,02-1,04$ & 1,03 & $1,02-1,04$ & 1,02 & $1,01-1,04$ & 1,04 & $1,03-1,06$ \\
\hline & 25 år & 1 & - & 1 & - & 1 & - & 1 & - & 1 & - \\
\hline & Utdanningsnivå & & & & & & & & & & \\
\hline & Obligatorisk & 1,95 & $1,28-2,96$ & 1,76 & $1,16-2,66$ & 1,83 & $1,15-2,90$ & 2,16 & $1,25-3,75$ & 2,18 & $1,32-3,61$ \\
\hline & Mellomutdanning & 1,38 & $0,98-1,95$ & 1,09 & $0,77-1,54$ & 1,09 & $0,78-1,53$ & 1,15 & $0,79-1,67$ & 1,28 & $0,82-2,00$ \\
\hline & Universitet/høyskole & 1 & - & 1 & - & 1 & - & 1 & - & 1 & - \\
\hline & Selvrapportert helse & & & & & & & & & & \\
\hline & Dårlig helse & 1,69 & $1,20-2,39$ & 1,98 & $1,41-2,80$ & 1,63 & $1,11-2,39$ & 2,42 & $1,49-3,94$ & 2,10 & $1,40-3,16$ \\
\hline & God helse & 1 & - & 1 & - & 1 & - & 1 & - & 1 & - \\
\hline \multirow[t]{6}{*}{$2 a}$. & Alder i år & 1,03 & $1,02-1,04$ & 1,03 & $1,02-1,04$ & 1,03 & $1,01-1,04$ & 1,02 & $1,00-1,03$ & 1,04 & $1,02-1,06$ \\
\hline & 25 år & 1 & - & 1 & - & 1 & - & 1 & - & 1 & - \\
\hline & Utdanningsnivå & & & & & & & & & & \\
\hline & Obligatorisk & 1,51 & $0,98-2,34$ & 1,40 & $0,91-2,15$ & 1,47 & $0,91-2,36$ & 1,87 & $1,06-3,28$ & 1,60 & $0,95-2,69$ \\
\hline & Mellomutdanning & 1,37 & $0,96-1,94$ & 1,07 & $0,76-1,52$ & 1,08 & $0,77-1,52$ & 1,14 & $0,78-1,66$ & 1,23 & $0,78-1,94$ \\
\hline & Universitet/høyskole & 1 & - & 1 & - & 1 & - & 1 & - & 1 & - \\
\hline \multirow[t]{9}{*}{$2 b$} & Alder i år & 1,03 & $1,02-1,04$ & 1,02 & $1,01-1,04$ & 1,02 & $1,01-1,04$ & 1,01 & $1,00-1,03$ & 1,04 & $1,02-1,05$ \\
\hline & 25 år & 1 & - & 1 & - & 1 & - & 1 & - & 1 & - \\
\hline & Utdanningsnivå & & & & & & & & & & \\
\hline & Obligatorisk & 1,45 & $0,94-2,25$ & 1,30 & $0,84-2,01$ & 1,40 & $0,87-2,27$ & 1,71 & $0,97-3,02$ & 1,50 & $0,88-2,54$ \\
\hline & Mellomutdanning & 1,35 & $0,95-1,92$ & 1,05 & $0,74-1,49$ & 1,07 & $0,76-1,50$ & 1,11 & $0,76-1,62$ & 1,22 & $0,77-1,93$ \\
\hline & Universitet/høyskole & 1 & - & 1 & - & 1 & - & 1 & - & 1 & - \\
\hline & Selvrapportert helse & & & & & & & & & & \\
\hline & Dårlig helse & 1,36 & $0,95-1,96$ & 1,68 & $1,17-2,40$ & 1,38 & $0,93-2,06$ & 2,08 & $1,27-3,42$ & 1,61 & $1,05-2,47$ \\
\hline & God helse & 1 & - & 1 & - & 1 & - & 1 & - & 1 & - \\
\hline
\end{tabular}


Herunder inngår forhold relatert til bosted (så som nærhet og tilgjengelighet til legetjenester), økonomi, familiesituasjon og sosiale nettverk, så vel som helsetilstand, tidligere erfaringer med helsetjenesten, og helserelaterte normer og verdier. Om vi avgrenser diskusjonen til det siste forholdet, kan vi tolke svarene som uttrykk for individuelle og kulturelle variasjoner i:

- Forventninger til kropp og helse, herunder tolking av kroppslige symptomer, toleranse for kroppslige plager, og oppfatninger om hva den gode helse utgjør

- Troen på egen mestringsevne og på profesjonell medisinsk ekspertise

- Normer omkring legesøkning, altså hvordan man mener man bør tenke om hva som er et akseptabelt forbruk av legetjenester

De tre faktorene-hva vi aksepterer av plager, hva vi tror om hvor hjelpen ligger, og hva vi mener vi bør gjøre - virker trolig i et komplekst og usystematisk samspill. Oppfatningen om at vi ikke bør søke lege før det er absolutt påkrevet, er ikke nødvendigvis ledsaget av høy tro på egne krefter og høy tålegrense: $\mathrm{Vi}$ kan for eksempel mene at legesøkning bør unngås såfremt det er mulig, men likevel ha høy tro på profesjonell helsehjelp og lav tålegrense. Denne kompleksiteten gjør det vanskelig å trekke konklusjoner om hva analyseresultatene er et uttrykk for.

Ettersom terskelen for hypotetisk legesøkning er sammensatt av mange ulike delfaktorer, mens mønsteret i svargivningen er relativt konsistent, er det lite sannsynlig at terskelhypotesen alene kan forklare våre funn. En alternativ hypotese er derfor at de systematiske mønstrene tilsier at informantene kan forstås som kulturbærere, og at deres individuelt uttrykte holdninger kan tolkes som kulturelle normer og verdier for den utdanningsgruppen de tilhører. Analyseresultatene er i så fall et uttrykk for kulturelle variasjoner mellom utdanningsgruppene, ved at kulturelle normer og verdier knyttet til legesøkning er systematisk forbundet med utdanningsnivå for kvinner. Et eksempel: Hvilke normer og verdier gjelder når spørs- målet er hvorvidt det er bra eller dårlig å søke legehjelp for å håndtere mindre kroppslige plager? Resultatene indikerer at normen «man bør helst klare seg selv» står sterkere blant de høyt enn blant de lavt utdannede kvinnene. Det er altså kanskje ikke like sosialt og kulturelt akseptabelt for en høyt utdannet kvinne å si at hun går til legen for vondt i hodet eller halsen - og slik kanskje vedgå at hun ikke stoler på egne krefter eller mestrer slike plager på egen hånd - som for en kvinne med lavere utdanningsnivå.

\section{Har utdanning ulik effekt}

på menns og kvinners legesøkning?

Resultatene viste beskjedne forskjeller i hypotetisk legesøkning mellom kjønnene. Vi kan altså ikke hevde at menn har en vesentlig lavere terskel for hypotetisk legesøkning enn kvinner - eller omvendt. Dette stemmer godt overens med funn fra tidligere studier $(12,13)$. På samme tid ser det ut til at det er en forskjell mellom menn og kvinner hva gjelder betydningen av henholdsvis utdanning og helse på sannsynligheten for å velge

Tabell 5 Logistiske regresjonsanalyser, kvinner: Ville gått til lege først for råd eller behandling dersom de hadde (...)

\begin{tabular}{|c|c|c|c|c|c|c|c|c|c|c|c|}
\hline & \multirow[b]{3}{*}{ Uavhengige variabler } & \multicolumn{10}{|c|}{ Avhengige variabler (holdningsvariabler) } \\
\hline & & \multicolumn{2}{|c|}{$\begin{array}{l}\text {...veldig } \\
\text { sår hals } \\
\text { (n=694) }\end{array}$} & \multicolumn{2}{|c|}{$\begin{array}{l}\text {...kraftig } \\
\text { hodepine } \\
(n=694)\end{array}$} & \multicolumn{2}{|c|}{$\begin{array}{c}\text {...alvorlige } \\
\text { søvnproblemer } \\
(n=692)\end{array}$} & \multicolumn{2}{|c|}{$\begin{array}{l}\text {...sterke } \\
\text { ryggsmerter } \\
\text { (n=694) }\end{array}$} & \multicolumn{2}{|c|}{$\begin{array}{l}\text {...alle fire } \\
\text { symptom } \\
(n=692)\end{array}$} \\
\hline & & OR & $95 \% \mathrm{KI}$ & OR & $95 \% \mathrm{KI}$ & OR & $95 \% \mathrm{KI}$ & OR & $95 \% \mathrm{KI}$ & OR & $95 \% \mathrm{KI}$ \\
\hline \multirow[t]{9}{*}{1.} & Alder i år & 1,02 & $1,01-1,03$ & 1,04 & $1,03-1,05$ & 1,02 & $1,01-1,03$ & 1,01 & $1,00-1,02$ & 1,05 & $1,03-1,06$ \\
\hline & 25 år & 1 & - & 1 & - & 1 & - & 1 & - & 1 & - \\
\hline & Utdanningsnivå & & & & & & & & & & \\
\hline & Obligatorisk & 2,56 & $1,66-3,94$ & 2,53 & $1,66-3,84$ & 1,99 & $1,28-3,10$ & 2,15 & $1,27-3,63$ & 4,80 & $2,74-8,40$ \\
\hline & Mellomutdanning & 1,66 & $1,15-2,41$ & 1,29 & $0,90-1,84$ & 1,49 & $1,05-2,10$ & 1,27 & $0,87-1,85$ & 1,51 & $0,86-2,65$ \\
\hline & Universitet/høyskole & 1 & - & 1 & - & 1 & - & 1 & - & 1 & - \\
\hline & Selvrapportert helse & & & & & & & & & & \\
\hline & Dårlig helse & 1,19 & $0,83-1,69$ & 1,62 & $1,15-2,29$ & 1,52 & $1,05-2,18$ & 1,60 & $1,05-2,44$ & 1,40 & $0,88-2,22$ \\
\hline & God helse & 1 & - & 1 & - & 1 & - & 1 & - & 1 & - \\
\hline \multirow[t]{6}{*}{$2 a}$. & Alder i år & 1,01 & $1,00-1,03$ & 1,04 & $1,02-1,05$ & 1,01 & $1,00-1,03$ & 1,00 & $0,99-1,02$ & 1,03 & $1,01-1,05$ \\
\hline & 25 år & 1 & - & 1 & - & 1 & - & 1 & - & 1 & - \\
\hline & Utdanningsnivå & & & & & & & & & & \\
\hline & Obligatorisk & 2,21 & $1,39-3,52$ & 1,66 & $1,05-2,61$ & 1,71 & $1,07-2,75$ & 2,07 & $1,19-3,62$ & 3,30 & $1,81-6,02$ \\
\hline & Mellomutdanning & 1,58 & $1,09-2,30$ & 1,11 & $0,77-1,60$ & 1,42 & $1,00-2,01$ & 1,25 & $0,85-1,84$ & 1,32 & $0,75-2,33$ \\
\hline & Universitet/høyskole & 1 & - & 1 & - & 1 & - & 1 & - & 1 & - \\
\hline \multirow[t]{9}{*}{$2 b$. } & Alder i år & 1,01 & $1,00-1,03$ & 1,03 & $1,02-1,05$ & 1,01 & $1,00-1,02$ & 1,00 & $0,99-1,02$ & 1,03 & $1,01-1,05$ \\
\hline & $25 a ̊ r$ & 1 & - & 1 & - & 1 & - & 1 & - & 1 & - \\
\hline & Utdanningsnivå & & & & & & & & & & \\
\hline & Obligatorisk & 2,24 & $1,40-3,58$ & 1,62 & $1,02-2,56$ & 1,65 & $1,02-2,66$ & 1,96 & $1,12-3,45$ & 3,37 & $1,84-6,19$ \\
\hline & Mellomutdanning & 1,60 & $1,10-2,33$ & 1,09 & $0,75-1,58$ & 1,38 & $0,97-1,97$ & 1,21 & $0,82-1,78$ & 1,34 & $0,75-2,37$ \\
\hline & Universitet/høyskole & 1 & - & 1 & - & 1 & - & 1 & - & 1 & - \\
\hline & Selvrapportert helse & & & & & & & & & & \\
\hline & Dårlig helse & 0,92 & $0,63-1,35$ & 1,17 & $0,81-1,69$ & 1,27 & $0,87-1,86$ & 1,43 & $0,92-2,23$ & 0,88 & $0,53-1,45$ \\
\hline & God helse & 1 & - & 1 & - & 1 & - & 1 & - & 1 & - \\
\hline
\end{tabular}


lege, da samvariasjonen mellom utdanning og hypotetisk legesøkning er sterkere for kvinner enn for menn, mens samvariasjonen mellom helse og hypotetisk legesøkning er sterkere for menn enn for kvinner.

Våre analyser indikerer at terskelen for hypotetisk legesøkning, spesielt for kvinner, varierer med sosioøkonomisk posisjon. Tidligere studier av sammenhengen mellom utdanning og hypotetisk legesøkning $(12,14$, 15) har funnet tilsvarende utdanningsrelaterte mønstre, men utdanningens tilsynelatende ulike betydning for kvinners og menns holdninger er ikke tidligere rapportert.

\section{Begrensninger ved studien}

Ettersom alle data er samlet på samme tid, kan vi ikke fastslå retningen på signifikante assosiasjoner i datasettet. De konkrete symptomene studien tar utgangspunkt i, utgjør videre et begrenset utvalg av det vi kan betegne som mindre alvorlige plager. Resultatene kan derfor ikke generaliseres til andre og mer alvorlige tilstander. I tillegg er det en begrensning at resultatene av vår studie kun sier noe om normer og holdninger; hvorvidt disse normene reflekteres $i$ handling, er et åpent spørsmål.

Utvalget av forklaringsvariabler er imidlertid også beskjedent, og resultatene kan meget vel påvirkes i den ene eller annen retning dersom man her kontrollerer for flere mulige konfunderende faktorer. Det er for øvrig et interessant resultat at effekten av utdanning i analyser for menn blir ikke-signifikant justert for alder og helsetilstand. De observerte forskjeller i resultatet av de multivariable analyser på menn versus kvinner kan bety at effekten av utdanning på hypotetisk legesøkning er svakere for menn enn for kvinner (fig 1 og 2), at utdanning ikke har noen vesentlig betydning for menns hypotetiske legesøkning, eller at vår studie ikke har styrke nok til å påvise en slik effekt.

Forhold ved utdanningsvariabelen kan også ha påvirket resultatene. Den norske undersøkelsen hadde et selektivt frafall relatert til utdanningsnivå, noe som innebærer at respondenter med lavest utdanningsnivå er underrepresentert $\mathrm{i}$ forhold til respondenter med høyest utdanningsnivå $(7,16)$. Utdanning er dessuten selvrapportert i ESS, og det selv- rapporterte utdanningsnivået avviker fra registerbaserte utdanningsdata for utvalget. Avviket er større blant menn, og overrapportering av nivå et større problem enn underrapportering. Problemets omfang reduseres imidlertic dersom man legger til grunn en tredelt utdanningsvariabel lik den benyttet her (16).

\section{Konklusjon}

Holdninger til hypotetisk legesøkning i den norske befolkningen, spesielt blant kvinner, ser ut til å være sosialt strukturert på bakgrunn av utdanning. Vår tolking av de utdanningsrelaterte forskjellene $\mathrm{i}$ hypotetisk legesøkning for kvinner er at disse mønstrene ikke er uttrykk for individuelle holdninger, men for kulturelle normer og verdier Resultatene sier altså noe om hvordan ulike sosiale lag i befolkningen oppfatter at de $b ø r$ tenke og handle, og hva som i deres kultur regnes som sosialt akseptabelt i gitte situasjoner. Når de utdanningsrelaterte mønstre for kvinner videre er såpass systematisk fordelt mellom utdanningsgruppene, kan det tyde på at utdanning påvirker normer for legesøkning.

e-tab 1, e-tab 2, e-tab 3, e-fig 3 og e-fig 4 finnes kun i Tidsskriftets nettutgave.

\section{Olaug S. Lian (f. 1964)}

er dr.polit. i sosiologi, førsteamanuensis

i medisinsk sosiologi ved Universitetet

¡ Troms $\varnothing$, og forskningsveileder ved Universi-

tetssykehuset Nord-Norge.

Ingen oppgitte interessekonflikter.

\section{Birgitte Klüwer-Trotter (f. 1981)}

er bachelor i sykepleie og master i folkehelsevitenskap, Universitetet i Tromsø.

Ingen oppgitte interessekonflikter.

\section{Litteratur}

1. St.meld nr. 20 (2006-2007). Nasjonal strategi for å utjevne sosiale helseforskjeller. Oslo: Helseog omsorgsdepartementet, 2007.

2. Strand BH, Grøholt E-K, Steingrímsdóttir ÓA et al. Educational inequalities in mortality over four decades in Norway: prospective study of middle aged men and women followed for cause-specific mortality, 1960-2000. BMJ 2010: 340: c654 doi: 10.1136/bmj.c654.
3. Korsnes 0 red. Sosiologisk leksikon. Oslo: Universitetsforlaget, 2008: 113-14.

4. Den europeiske samfunnsundersøkelsen. ESS Round 2: European Social Survey Round 2 Data (2004). Data file edition 3.1. Norwegian Social Science Data Services, Norway - Data Archive and distributor of ESS data. Bergen: Norsk samfunnsvitenskapelige datatjeneste, 2004 http://ess.nsd.uib.no/ (18.11.2011).

5. Den europeiske samfunnsundersøkelsen. ESS Round 2: European Social Survey (2008): ESS-2 2004 Documentation Report. Edition 3.2. European Social Survey Data Archive, Norwegian Social Science Data Services. Bergen: Norsk samfunnsvitenskapelige datatjeneste, 2008 http://ess.nsd.uib.no/ (18.11.2011)

6. Norsk samfunnsvitenskapelig datatjeneste. ESS Data - European Social Survey Data archive. http://ess.nsd.uib.no/ (18.11.2011).

7. Stoop I, Billiet J, Koch A et al. Improving survey response: Lessons learned from the European Social Survey. Chichester: John Wiley, 2010

8. Elstad JI. Utdanning og helseulikheter: Problemstillinger og forskningsfunn. IS-1573. Oslo: Helsedirektoratet, 2008

9. SSB. Norsk standard for utdanningsgruppering Revidert 2000. Oslo: Statistisk sentralbyrå, 2001.

10. Eikemo TA. Social inequalities in self-assessed health between European welfare regimes: evidence from the European Social Survey. Doktoravhandling. Trondheim: Norges teknisk-naturvitenskapelige universitet, 2008: 147.

11. Westin M, Åhs A, Bränd Persson K et al. A large proportion of Swedish citizens refrain from seeking medical care-lack of confidence in the medical services a plausible explanation? Health Policy 2004; 68: 333-44. doi: 10.1016/ jhealthpol 2003.10.008 PubMed

12. Adamson J, Ben-Shlomo Y, Chaturvedi $\mathrm{N}$ et al. Ethnicity, socio-economic position and gender-do they affect reported health-care seeking behaviour? Soc Sci Med 2003: 57: 895-904 doi: $10.1016 /$ S0277-9536(02)00458-6 PubMed

13. Wyke S, Hunt K, Ford G. Gender differences in consulting a general practitioner for common symptoms of minor illness. Soc Sci Med 1998; 46. 901 -6. doi: 10.1016/S0277-9536197100217-7 PubMed

14. van der Meer JB, Mackenbach JP. Low education, high GP consultation rates: the effect of psychosocial factors. J Psychosom Res 1998; 44: 587-97. doi: 10.1016/S0022-3999(97)00217-1 PubMed

15. Grosse Frie K, Eikemo TA, von dem Knesebeck 0 . Education and self-reported health care seeking behaviour in European welfare regimes: results from the European Social Survey Int J Public Health 2010; 55: 217-20. doi: 10.1007/ s00038-009-0073-3 PubMed

16. Kleven $\emptyset$. Ringdal K. A comparison of two ways of measuring level of education in Norway: Questions in survey interviews versus register data. http://ess.nsd.uib.no/bibliography/details/ publication/181 (7.12.2011).

Mottatt 30.3. 2011, første revisjon innsendt 16.6 2011, godkjent 3.11. 2011. Medisinsk redaktør Siri Lunde. 